\title{
Expressive Feedback Functions in the Conversation of The Radio Visitation Program
}

\author{
Wiwik Yulianti \\ student of Pragmatic Linguistics \\ Postgraduate Program of UNS Surakarta \\ ipeyulia@gmail.com \\ Sumarlam \\ Faculty of Language and Art \\ Universitas Sebelas Maret, Indonesia \\ sumarlam@gmail.com
}

\author{
Muhammad Rohmadi \\ Faculty of Language and Art \\ Universitas Sebelas Maret, Indonesia
}

\begin{abstract}
Radio broadcast (broadcast) or better known as radio is one means of electronic communication used by the public to obtain information, send information and obtain entertainment that is auditive (Onong, 1990, p. 18). The purpose of this study is to know the type of expressive speech acts contained in the radio visitation program. The purpose of this study is to know the type of expressive speech acts contained in the radio visitation program. the method used in this research is the method of referring and notes. Using advanced techniques of recording techniques, techniques of free libat ably proficient, record techniques, and interview techniques. Data analysis in this research using method of padan pragmatic. This pragmatic method is applied using a contextual approach to the aspects proposed by leech (1993). Expressive utterances or expressive speech acts are speech acts intended by the speaker for his utterance to be interpreted as an evaluation of what is mentioned in the speech. This form of speech has a function to express or express the psychological attitude of the speaker to his or her opponent. The function refers to the purpose of the utterance in its use to express judgment is called the expressive pragmatic function (Rustono 2000 , p. 106). The findings of this research are expressive speech acting functions found in conversations in the radio visitation program, expressive speech function, expressive speech function congratulating, expressive speech fingsi apologizing, expressive speech function blaming, expressive speech function praised, speech function expressive complaining, expressive expressive speech function, and expressive expressive speech function.
\end{abstract} function

Keywords-speech; expressive; radio; pragmatic; speech

\section{INTRODUCTION}

Radio broadcast or better known as radio is one means of electronic communication used by the public to obtain information, send information and obtain entertainment that is auditive (Onong, 1990, p. 18). There are two kinds of radio broadcasts known to the public, namely government radio and private radio. However, the existence of private radio today is increasingly increasing the quantity and quality.

As one of the common means of communication, radio has a variety of programs presented in various forms as a variety or variation, based on heterogeneous audience segmentation in terms of age, gender, profession, social status, economy, and so forth. With such heterogeneous listeners, radio managers must be able to organize and create events that meet the demands of their listeners. Therefore, the managers of competing radio make an interesting event, so it can capture a lot of listeners.

One of the many radio shows enjoyed by listeners is a radio visitation program or commonly known as a song request program by listeners with sending greetings to other listeners involving broadcasters and listeners by means of interactive telephony. The visitation event is hosted by a radio broadcaster acting as a speaker or first person (01) and a listener as a participant acting as a speech or second person (02). Familiarity between broadcasters and listeners makes the radio still popular today. The fact that is happening now, broadcast radio still has a loyal audience who always listen to radio programs. This is evident from the radio show visitation program is still a popular listener to visit, sending directly communicate with the broadcaster over the phone. Radio broadcasters' expression capabilities using language aim to influence the listener to be willing to follow what the broadcaster wants. Broadcasters of radio visitation programs have the task of providing information, entertainment and inviting listeners to participate by phone or other means to communicate directly with the broadcaster to be able to send greetings and visit other listeners on air.

There are a variety of speech acts done by radio broadcasters to invite listeners to interact. The expressive speech acting function in conversations of the radio visitation program is interesting to research because the interaction of the broadcaster and the listener that occurs is natural without the previous scenario. While radio broadcasters can maximize expressive speech acting functions to attract more listeners to the radio visitation program. 


\section{LITERATURE REVIEW}

\section{A. Speech acts the theory}

Searle (1969) classifies speech acts into five types, namely (1) speech acts, (2) directive, (3) expressive, (4) commissive, and (5) declarative. The speech of a representative is a speech act that binds the speaker to the correctness. The act of speech directive is a speech act done by the speaker to speak the action mentioned in the speech. Speech directives include speech acts enjoining, pleading, suggesting, appealing, and counseling. The act of expressive speech is a speech act that is done with the intent to assess or evaluate the things mentioned in his speech. Praise and criticism are classified as expressive speech acts. The act of commissive speech is a speech act that binds the speaker to carry out the things mentioned in the speech. Promise or swear is included in commissive speech acts. Declarative speech acts are acts of speech performed with the intention of creating a new state. Undo and allow including speech acts. The subject of this analysis is the analysis of speech act based on the context

\section{B. Context}

Pateda (1994) says that in essence context theory is (1) the meaning is not in the tangible elements of the word. But integrated into the utterance as a whole and (2) the meaning should not be interpreted in a dualist way (word and reference) or a trialist (word, reference and interpretation) but a function or task in speech affected by the situation. Different understandings of a common utterance, such as the example above, are due to the social context of social status, rights and duties, and experiences experienced by the participants. According to Leech (1983, pp. 13-4), the context of speech situations includes the following aspects:

1) Speakers and speech partners covering aspects related to this speech participants, such as age, socioeconomic background, gender, level of intimacy, and others.

2) The context of speech is the context in all aspects of the physical (kotex) and relevant social settings of the relevant speech (context) (see also Yule, 1985, p. 99 in Cahyono 1995, p. 214-215, Poedjosoedarmo, 2001, p. 112)

3) The purpose of the speech speech form is spoken by the speakers backed by a particular purpose and purpose.

4) Speech as a form of action or activity, meaning a speech associated with verbal acts that occur in certain situations.

5) Speech as a verbal action product, means that the resulting speech is a form of verbal action.

\section{Expressive Speech Acts}

According to Kreidler (1998, p. 183) expressive speech acts are acts of speech performed with the intention that his speech is interpreted as an evaluation of the things mentioned in the speech, such as say greetings, say sorry, condolence, and refused. This speech reflects a psychological statement. The wording refers to expressive speech types marked with verb forms such as apologizing, rejecting, and acknowledging. Felicity conditions "expressiveness condition" expressive speech acts orientation on the speaker's self, namely the possibility of an action and speakers have the ability, speakers serious in the speech, and partners said to believe the speech speakers.

Expressive speech acts rests on the actions the speaker has taken or may be the result of the current action. Thus expressive expressiveness is retrospective and involves the speaker. Expressive expressions arise when the speaker tells of his own past actions and his present feelings, which can be conveyed through apology, gibberish, and regret. The commonly used expressive verb (in expressive context) is to legitimate, acknowledge, deny/reject and forgive. According to Searle (in Rahardi, 2005, p. 36) expressive speech act is a form of speech that serves to express or show the psychological attitude of the speaker to a situation, such as thanking (thanking), congratulating, pardoning, blambing), praising, condoling.

\section{RESULT AND DISCUSSION}

The pragmatic function of speech acts is a function referred to by the utterance of speech in its use to communicate between speakers (Rustono 2000, p. 92). Expressive utterances or expressive speech acts are speech acts intended by the speaker for his utterance to be interpreted as an evaluation of what is mentioned in the speech. This form of speech has a function to express or express the psychological attitude of the speaker to his or her opponent. The function referred to by the utterance of speech in its use to express judgment is called the expressive pragmatic function (Rustono 2000, p. 106). With this pragmatic function, speakers intend to judge on what it says. As for some expressive speech functions contained in an utterance delivered by the speaker to his opponent, which can serve to congratulate, thank you, criticize, complain, blame, flatter/praise, apologize, and quip.

\section{1) Expressive speech function say happy}

The subfunction of congratulating is a speech that binds the speaker to express the psychological attitude intended for his utterance to be interpreted as an evaluation with the utterance of congratulating. Expressive congratulatory utterance is an act of speech that occurs due to several factors, namely speakers get something special, speakers give a special welcome to the opponent said, or as a welcome or greeting time marker so that his opponent said congratulate the speaker as an expression of happiness.

Data [01]

$\begin{array}{ll}\text { Wanda } & \text { : Afternoon, who is this? [1] } \\ \text { Caller } & \text { : Who is hayoo ...? [2] } \\ \text { Wanda } & \text { : who.....?? [3] } \\ \text { Caller } & \text { : hahaha .... anyone try it? [4] } \\ \text { Wanda } & \text { : Oh, .. mbak nana in solo .... [5] } \\ \text { Caller } & : \text { you knows.. wanda [6] } \\ \text { Wanda } & \text { : i know..e.good luck Today is your } \\ & \text { birthday, how many? [7] } \\ \text { Caller } & \text { : who? ........ [8] }\end{array}$




\author{
Wanda : Happy birthday .... long life huh? \\ [9] \\ Caller : Thanks wanda [10]
}

In the above data [01], the broadcaster (speaker) [7] gives birthday wishes to the caller (opponent of speech) for celebrating the special day of the birthday. Speakers [9] give special remarks of birthday greetings to the opponents of the speech celebrating the birthday .

\section{2) Express speech functions say thank you}

The thankful subfunction is a speech that binds the speaker to express the psychological attitude intended for his speech to be interpreted as an evaluation by saying thank you. Expressive utterance speech is a speech act which usually occurs due to several factors such as, because the spoken or speaking partner is willing to do what is required by the speaker, due to the speech 'praise' spoken by the speaker to the opponent of speech, or due to the kindness of the speaker has given something to the opponent said. Data [02]

$\begin{array}{ll}\text { Broadcaster } & \text { : okay / your greeting? / [1] } \\ \text { Caller } & \text { : to be heard alone aja // [2] } \\ \text { Broadcaster } & \text { : oho okee / [3] } \\ \text { Caller } & \text { : again on the bed / [4] } \\ \text { Announcer } & \text { : again / rilax ya sir yaa // [5] } \\ \text { Caller } & \text { : yes rilax / [6] } \\ \text { Broadcaster } & \text { : hehe okay / later song awaited yes } \\ & \text { sir yes / / [7] } \\ \text { Caller } & \text { : yes thanks / [8] } \\ \text { Broadcaster } & \text { : okay thanks again / [9] }\end{array}$

In the data [02] above caller [8] said thank you to the broadcaster, because the broadcaster is willing to play the caller's call. While the announcer [9] said thanks to the caller again, because the caller is patient until the song is played. Expressive expressions thank you happily because the spoken or spokeswoman is willing to perform the activities desired by the speaker.

\section{3) Express speaking functions complain}

The complaining subfunction is a speech that binds its penutter to express the psychological attitude intended for its utterance to be interpreted as an evaluation in a complaining utterance. Expressive expressive utterance is a speech act that occurs because it wants to express the pain caused by suffering, pain, or disappointment.

Data [03]

$\begin{array}{ll}\text { Caller } & \text { : make Mama endi good afternoon / } \\ & \text { to emm also what are you doing ya .. } \\ & \text { / also for grandfather petrus / was } \\ & \text { rush also for grandfather petrus right } \\ & /[1] \\ \text { Announcer } & : \text { yes .. yeah petrus yesterday ask for } \\ \text { selfi / [2] } & \\ \text { Caller } & \text { : ohh so yes // oo [3] } \\ \text { Broadcaster: he em [4] } \\ \text { Caller } & : \text { I am not invited yesterday / [5] }\end{array}$

\author{
Announcer : oh .. next time ya ya ya hhaha our \\ selfi with me ya / [6] \\ Caller : : o instih / oke mbak nia / [7] \\ Broadcaster : okay [8]
}

In the above speech [03], the caller tells the speech [5] "I am not invited yesterday" which expresses the difficulty of not being invited to the event by the previous broadcaster and grandfather of Peter. the sense of disappointment of the caller seen in the speech.

4) Express speaking functions blame

The blame subfunction is a speech that binds the speaker to express the psychological attitude intended for his utterance to be interpreted as an evaluation in the blame speech. Speech expressive blame is a speech act that occurs due to several factors, namely because of an error made by the opponent said, because the opponent said not willing to be responsible for his mistakes, or because the opponent said to escape from a mistake.

Data [04]

\begin{tabular}{|c|c|}
\hline Caller I & $\begin{array}{l}\text { : Marriage again kak, have a } \\
\text { girlfriend then married again so [1] }\end{array}$ \\
\hline $\operatorname{Max}$ & : He'eh .. then ya find a boyfriend [2] \\
\hline $\begin{array}{l}\text { Caller I } \\
\text { what the }\end{array}$ & $\begin{array}{l}\text { : What does it look like? If dah lyrics, } \\
\text { ? Can not [3] }\end{array}$ \\
\hline Max & : How can I not? He said guys .. [4] \\
\hline Caller I & : Yeah that's hard [5] \\
\hline Max & $\begin{array}{l}\text { : Yes it must be gentle ... so guys } \\
\text { must be brave. [6] }\end{array}$ \\
\hline Caller I & $\begin{array}{l}\text { : Yeah how the girls are that hard, } \\
\text { righteous these five years [7] }\end{array}$ \\
\hline Max & $\begin{array}{l}\text { : Ow means you also have to correct } \\
\text { yourself, what about? [8] }\end{array}$ \\
\hline Caller I & $\begin{array}{l}\text { : Yes I lack connectivity, } \\
\text { koneksivitas like konek ... not yet [9] }\end{array}$ \\
\hline Max & : Who does this mean? [10] \\
\hline Caller I & : the connector is not there yet $[11]$ \\
\hline
\end{tabular}

Speeches contained in the data [04] above, show some speech that is blaming the caller for not knowing how to get the girl coveted. Speech [4] is a speech aimed at blaming the opponent for not being able to get a partner. In speech [8] also speech is intended to blame the opponent of speech for self-introspection, approximately what makes the opponent said can not find a partner. Speakers try to blame the actions of the opponent.

\section{5) Express speaking function flatter/praise}

Flattering subservant is a utterance that binds its speaker to express the psychological attitude intended for his utterance to be interpreted as an evaluation with flattery or praise. Expressive speech is flattering or praising is a speech act that occurs due to several factors, namely due to the condition of the opponent said in accordance with the fact that there, because the speaker wants to relieve the opponent's heart, because the speaker wants to seduce the opponent said, because the speaker wants to please the opponent said, or because of the commendable acts committed by the speaker. 
Data [05]

$$
\begin{aligned}
& \text { Caller : :it, the sky lagune collapsed from } \\
& \text { Samson" [1] }
\end{aligned}
$$
heart

Broadcaster : hemmm [13]

Caller : greetings for mas Febri aja more handsome [14]

Broadcaster : yes [15]

Caller : add handsome, add what yes, clever, add a lot of money, add job where [16]

Broadcaster : thank you, thank you, thank you [17]

Caller : the song is not purple yes mas ya, just wrote there Luna mbak, it's also mbak Ine, the main one who often join join it yes [18]

Speaking on data [05] is expressive expression speech. Speech [10] and speech [11] in the above data are expressive speech praises because the speaker wants to woo the opponent of the speech, so that the requested song requests can be spun. Speakers want to please the opponent said that his desire to listen to his favorite song can be grante.

\section{6) Express speech function apologize}

Expressive expressive utterance is an act of speech that occurs due to several factors, namely because the opponent's request, because the feelings of uncomfortable speakers to the opponent said, because it has disturbed the opponent's time of speech, or for having made a mistake.

Data [06]

We go to one caller ulu ya meta miersa yes we greet first been queuing behind ya ya / who

Announcer : good afternoon / [1]

Caller : : good afternoon mbak ninaa / [2]

Broadcaster : mbak nia // hehe / [3]

Caller : odd reverse, sorry ya mbak nia / [4]

Broadcaster : no papa .. / [5]

Caller : still remember with my voice? / [6]

Broadcaster : emm [7]
Caller : : yesterday met yesterday / eee not yet remember yaa /oke yess // [8]

Speaking on data [06] above is expressive speech apologizing. In the speech [4] "Alas reverse, Sorry ya mbak nia" shows feelings of discomfort to the opponent because the error he did guess who the voice is on duty broadcast.

7) Express express satisfaction function

Speech expressive sarcastic is a speech that occurs due to several factors, ie speakers do not like what is done or spoken opponent said, because speakers convey reasons that are not reasonable to the opponent said, or because the speech question of the speaker to the opponent said. Data [07]

Max : Whose is that? same girl so? [1]

Caller I : if the same Wini connect so [2]

Max : Ow ... What's that connecting? [3]

Caller I : Yes connect his mind [4]

Max : Sure? [5]

Caller I : Sure. What you connect doing times [6]

Caller I : Oh yes, this Wini guy is not a boyfriend either [7]

Max : Oh ... so, yes, so if you connect both of them are actually yes no. But, just connect your aja or Wininya or everything? [8]

Caller I : : Yes laughing so same Wini [9]

Max $\quad$ : Eeemm ... dare to speak directly not the same Wini? [10]

Caller I : Brave. [11]

Max : Yeah tomorrow the telephones themselves say yes. [12]

Caller I : Pin it, ask [13]

Max : Cemen really doing bbm, talking directly dong [14]

Speech on data [07] is an expressive speech that serves to quip. It is done to respond to the statement of the opponent who did not dare to approach the girl who approached. In speech [8] the speaker doubts the opponent's state of speech whether he really likes each other between the opponent and Wini (the woman who counted the opponent said) or just clap one hand.

\section{CONCLUSION}

In the above discussion shows that the conversation in the conversation of the radio visitation program has an expressive speech act, which has expressive speech acting function ie, expressive speech function congratulate, expressive speech function expressing gratitude, expressive speech function complaining, expressive speech function blame, expressive speech function flattering / praising, expressive speech function, apologetic expressive speech function. 


\section{References}

Cahyono, Bambang Yudi. (1998). Kristal-kristal ilmu bahasa. Surabaya: Airlangga University Press.

Kreidler, Charles W. (1998). Introducing english semantics. New York: Routledge.

Leech, Geoffrey. (1983). Principle of pragmatics. New York: Longman.

Onong Uchjana Effendi. (1990). Radio siaran teori dan praktik. Bandung: Mandar Maju.

Pateda, Mansoer. (1992). Sosiolinguistik. Bandung: Angkasa.

Poedjosoedarmo, Soepomo. (1985). Komponen tutur. Dalam perkembangan linguistik di Indonesia. Penyunting Soenjono Dardjowidjojo. Jakarta: Arcan.

Searle, Jhon R. (1969). Speech acts, an essay in the philosophy of language. Cambridge University Press.

Yule, George. (1996). Pragmatics. Oxford: Oxford University Press. 